\title{
Understanding Paternalistic Leadership on Innovation Management in Indonesia Insurance Sector
}

\author{
Dodi Wirawan Irawanto $^{1^{*}}$, Khusnul Rofida Novianti ${ }^{2}$ \\ ${ }^{1}$ Department of Management, Universitas Brawijaya, Malang, Indonesia \\ ${ }^{2}$ Department of Management, University of Muhammadiyah Malang, Malang, Indonesia \\ *Corresponding author. Email: dodi.wi@ub.ac.id
}

\begin{abstract}
The government has established a responsive and proactive governance system that is oriented towards work professionals and innovation management in fostering the employee's innovation spirit through the management role, namely the paternalistic leadership style, to create a credible and accountable governance system. This research aims to investigate the relationship between paternalistic leadership on innovation management in the Indonesian state-owned enterprises in the insurance sector. Using a quantitative approach, 100 respondents participated, and the responses were analyzed using SPSS software with multiple regression analysis. The study revealed that paternalistic leadership has a significant effect on innovation management both partially and simultaneously. This means that all aspects of paternalistic leadership are perceived positively in Indonesia's employees of state-owned enterprises in the insurance sector.
\end{abstract}

Keywords: Paternalistic Leadership, Innovation Management, Indonesia, Insurance Sector

\section{INTRODUCTION}

The government has built a government governance structure that is responsive and oriented to work professionals to produce a credible and responsible government system. The function of leaders in directing everything related to the administration of the government system by referring to the applicable law and the prevailing organizational value system is ideally inextricably linked to credible and accountable governance. The current leadership climate has a considerable indirect influence on individual values in the firm. In the case of Indonesia, in response to the increasing prevalence of corruption, collusion, and nepotism [1], particularly in this era of regional autonomy [2], a leadership model is needed that is applicable in all sectors of people's lives, especially in government. Irawanto [3] proposes the Paternalistic leadership model, which is anchored in local culture and, when effectively executed, leads to organizational effectiveness. If paternalistic leadership has a good impact on civil employees' psychological well-being while performing their tasks, does it also ensure civil servants' commitment to honest and responsible governance?

Management innovation is a proactive move that an organization's management must take. Except for government insurance companies, which are obligated to serve as the government's insurance backbone [4]. Innovation management is defined in this study as a proactive attempt by organizational management to foster employees' innovation spirit through management roles, specifically an appropriate leadership style.

A comprehensive study of leadership literature can be concluded that the dominance of leadership research still uses theories originating from America, such as transformational leadership. Of course, this assumption is not true, because leaders often have difficulty in adapting to the cultures of their subordinates. In addition, in the world of research itself, transformational leadership is also considered as one of the successful leadership models of this century. The concept of paternalistic leadership has three elements that make up 
this leadership [5] including autocratic leadership, benevolent leadership, and moral leadership. Recent studies on paternalistic leadership in Indonesia [6 - 8] prove that paternalistic leadership is acceptable in the Indonesian context, especially for civil servants. The Indonesian version of Paternalistic leadership developed by Irawanto and Ramsey [7] is a leadership model with slightly different dimensions from the model developed by Taiwanese researchers, namely visible leadership, authoritarian leadership, virtuous leadership, moral leadership (i.e. no corruption, fairness, courage, and generosity). This research was focused to identify the relationship between paternalistic leadership on innovation management in the Indonesian state-owned enterprises in the insurance sector.

In the last decade, there has been an increasing evolution of leadership theories, and it can be concluded that most of these theories are based on western culture [9]. Some well-known leadership theories such as Vroom's situational leadership and David McClelland's motivational leadership were created and applied based on American culture, and are not appropriate for application outside the United States [10]. Moreover, being aware of the differences in national culture between one country and another does not mean that leadership theories created in certain countries will be successfully implemented in other countries [11, 12]. According to Littrell et al. [13], more than 3000 studies in the field of leadership have ruled out the important role of culture in forming good leadership. As a consequence, many leadership theories originating from western countries when implemented in non-western countries are not applicable and lead to malfunctioning practices.

Attempts to apply western leadership theory in non-western cultures may result in leadership ineffectiveness, as in Taiwan, where subordinates reject transformational leadership [5]. Furthermore, when compared to charismatic leadership, subordinates in Mexico favor patron leadership [14]. This could be because, according to Dorfman et al. [15], some leadership behaviors are culturally specific and have an impact on the flexibility with which leadership behaviors are implemented, so the application of these behaviors in one culture will undoubtedly differ from the application of these behaviors in another.

According to a review of leadership literature, the majority of leadership research still uses theories developed in the United States, such as transformational leadership and charismatic leadership [16]. Even Leithwood and Jantzi [17] anticipate that transformative leadership research will take over in the coming decade. This is due to the globalization issue, in which many international enterprises participate in a country's economy, so whether you like it or not, the leadership style at the head office will be applied to the country's branch offices. Of course, this notion is false, because leaders frequently struggle to adapt to their subordinates' cultures. Furthermore, transformational leadership is regarded as one of the most successful leadership models of this century in the research community, motivating academics to use this concept in their works [16, 18, 19]. However, because transformational leadership is formed in an individualist culture, it is not appropriate if this theory is implemented in a collectivist culture such as Indonesia. Jung et al. [19] have warned that if transformational leadership is implemented in a non-collectivist culture such as Indonesia, it will fail.

In terms of organizational culture, there are only two types: (1) individualist culture, which is prevalent in developed or western countries, and (2) collectivist culture, which is prevalent in developing or eastern countries. The study leverages secondary data from GLOBE's cross-country cultural studies [20] to show that there are cultural parallels between Chinese culture, as represented by Taiwan, and Indonesian culture, as represented by Javanese culture. Both promote collegial connections, feminine life principles, and a goal-oriented approach to work. Especially in the aspect of leadership, Irawanto and Ramsey [7] found that both Taiwan and Indonesia both applied the Paternal leadership model.

As can be seen, this leadership paradigm places a strong emphasis on morals and the father role in an organization. Even in this modern environment, paternalistic leadership is still evident in Taiwan [21]. This paternalistic leadership creates possibilities for "family" rituals, preserving values and conventions that promote obedience, loyalty, and morality in Taiwanese society today. On the other side, this principle can be seen in Indonesian culture, namely the philosophy of "discussion for consensus," which has been implanted in Indonesian society since childhood, making kinship a culture embedded in every Indonesian individual. Three 
elements make up paternalistic leadership [5] including (1) autocratic leadership; namely, a leadership style that upholds the value of absolute obedience and the supporting role of a leader; (2) benevolent leadership; namely, a leadership style that prioritizes others' interests and tolerance; and (3) moral leaders. Recent Indonesian research on paternalistic leadership [7, 8, 22] shows that paternalistic leadership is acceptable among government officials in Indonesia. Irawanto and Ramsey [7] established an Indonesian version of Paternalistic leadership, which has somewhat different characteristics from the model developed by Taiwanese scholars, namely: Visible Leadership, Authoritarian Leadership, Virtuous Leadership, and Moral Leadership (no corruption, fairness, courage, and generosity). Furthermore, various studies show that Indonesian civil servants are more concerned with the efficiency of their superiors' leadership as a model of leadership that is always present in front (visible) and preserves the moral principles of every dimension of moral leadership [7, 8 , 22].

Someone inventive will always want to enhance things by presenting something new/unique that is distinct from what is already available. Employees should also have the ability to think creatively. Employees who are always innovating in their firm will reap wealth and success. Innovativeness is a result of the characteristics of employees who can transform the environment around them. Employees and ordinary people, as well as entrepreneurs, are distinguished by their ability to be innovative. An employee will always consider doing something unique, rather than what the majorities of people thinks and do. The ability to transform less productive resources into productive resources to generate economic value is referred to as creative and innovative thinking. An employee is a person who may affect change in his surroundings, either directly or indirectly.

\section{RESEARCH METHODS}

Using a quantitative approach, this research tries to describe the relationship between paternalistic leadership on innovation management in the Indonesian state-owned enterprises in the insurance sector. Employees of state-owned insurance businesses with exceptional product innovations were surveyed for this study, which used population research. Purposive sampling was utilized to collect data. In this study, 100 respondents were drawn from four Indonesian state-owned insurance companies. Data measurement was carried out using a questionnaire, the first section part of the respondent demographic description and the second part measures paternalistic leadership aspects and innovation management responses. A five-point Likert scale was used for this research, ranging from 1 (strongly disagree) to 5 (strongly agree). Hypotheses were tested using multiple regression analysis using SPSS 23 software. In addition, the descriptive analysis will also be carried out to provide a better understanding of employees' positive perceptions of leadership styles based on local values.

\section{RESULTS AND DISUCSSION}

The following respondent description based on Table 1 majority was male, the majority has been married $62 \%$, $24 \%$ are aged between 41 till 45 and length of work mostly between 3 to 4 years.

Table 1. Respondent Demography

\begin{tabular}{|c|c|c|c|}
\hline Particulars & Items & $\begin{array}{l}\text { Frequency } \\
(\mathrm{N}=100)\end{array}$ & $\%$ \\
\hline \multirow{2}{*}{ Gender } & Male & 66 & 66 \\
\hline & Female & 34 & 34 \\
\hline \multirow{6}{*}{ Age (years) } & $20-25$ & 12 & 12.5 \\
\hline & $26-30$ & 22 & 22.3 \\
\hline & $31-35$ & 20 & 20 \\
\hline & $36-40$ & 12 & 12.5 \\
\hline & $41-45$ & 24 & 24.3 \\
\hline & $>46$ & 10 & 8.4 \\
\hline \multirow[t]{2}{*}{ Status } & Single & 38 & 38 \\
\hline & Married & 62 & 62 \\
\hline \multirow[t]{5}{*}{ Tenure } & $<1$ years & 9 & 9 \\
\hline & $1-2$ years & 24 & 24 \\
\hline & $3-4$ years & 32 & 32 \\
\hline & 5-6 years & 20 & 20 \\
\hline & $>6$ years & 15 & 15 \\
\hline \multirow[t]{4}{*}{ Education } & High School & 2 & 2 \\
\hline & Diploma & 6 & 6 \\
\hline & Bachelor & 79 & 79 \\
\hline & Master & 13 & 13 \\
\hline
\end{tabular}

The hypotheses in this study were tested using 
multiple regression analysis. To see if the data regression was suitable, three tests were done. First, there's data validation Table 5 shows that paternalistic leadership aspects had a relatively strong correlation to job innovation since it had an R-value of 0.896 or $89.6 \%$. The adjusted $\mathrm{R}$ square shows that all variables tested had an impact on job innovation with the magnitude of $80.3 \%$ and the remaining was affected by other variables not explored in this research and reliability (Table 2). The Cronbach's alpha reliability test is used to determine the reliability of acquired data. The result shows that the variable's Cronbach's alpha is 0.838 , and each item's factor load is greater than 0.5 , indicating that the instrument is valid and reliable. Second, the data were examined to check if it followed a normal distribution and if there was no evidence of multicollinearity. Both pairwise and multicollinearity are assessed using the tolerance value and the variance inflation factor (VIF) (Table 3).

Table 2. Reliability test

\begin{tabular}{|l|c|c|}
\hline Variable & Coefficient & Result \\
\hline Authoritarian Leadership & 0.961 & Reliable \\
\hline Visible Leadership & 0.890 & Reliable \\
\hline Moral Leadership (courage) & 0.776 & Reliable \\
\hline Moral Leadership (fairness) & 0.845 & Reliable \\
\hline $\begin{array}{l}\text { Moral Leadership (no } \\
\text { corruption) }\end{array}$ & 0.850 & Reliable \\
\hline Moral Leadership (generous) & 0.825 & Reliable \\
\hline Job Innovation & 0.906 & Reliable \\
\hline
\end{tabular}

Table 3. Multicollinearity test

\begin{tabular}{|l|c|c|}
\hline Variable & Tolerance & VIF \\
\hline Authoritarian Leadership & 0.780 & 1.281 \\
\hline Visible Leadership & 0.474 & 2.111 \\
\hline Moral Leadership (courage) & 0.750 & 1.333 \\
\hline Moral Leadership (fairness) & 0.516 & 1.937 \\
\hline Moral Leadership (no corruption) & 0.506 & 1.974 \\
\hline Moral Leadership (generous) & 0.565 & 1.769 \\
\hline
\end{tabular}

All of the tolerance values exceed 0.1 and the VIF result is below 10 . The result indicates that multicollinearity does not pose a serious problem and follows a normal distribution. Based on table 4, the result of the ANOVA test is significant $(\mathrm{F}=37.48$; $p<$ 0.000 ) and reveals a good fit between the data and the regression model. Table 5 shows the result of multiple regression analysis.

Table 4. The result of ANOVA test

\begin{tabular}{|l|l|c|l|l|}
\hline Model & $\begin{array}{l}\text { Sum of } \\
\text { Square }\end{array}$ & $d f$ & F & Sig \\
\hline Regression & 1712.565 & 6 & 37.480 & $.000^{\mathrm{b}}$ \\
\hline Residual & 418.854 & 55 & & \\
\hline Total & 2131.419 & 61 & & \\
\hline
\end{tabular}

Table 5 shows that paternalistic leadership aspects had a relatively strong correlation to job innovation since it had an R-value of 0.896 or $89.6 \%$. The adjusted $\mathrm{R}$ square shows that all variables tested had an impact on job innovation with the magnitude of $80.3 \%$ and the remaining was affected by other variables not explored in this research.

Table 5. The result of multiple regression

\begin{tabular}{|c|c|c|c|c|c|c|}
\hline Predictor & $\beta$ & SE & $\begin{array}{c}\text { Standardized } \\
\beta \\
\text { Coefficient }\end{array}$ & $T$ & Sig & Result \\
\hline Constant & -8.796 & $3 ., 353$ & & -2.623 & .011 & \\
\hline Authoritarian Leadership & -.068 & .041 & -.113 & -1.672 & .100 & Not Significant \\
\hline Visible Leadership & .309 & .087 & .309 & 3.557 & .001 & Significant \\
\hline Moral Leadership (courage) & .448 & .175 & .177 & 2.563 & .013 & Significant \\
\hline Moral Leadership (fairness) & .612 & .164 & .310 & 3.725 & .000 & Significant \\
\hline Moral Leadership (no corruption) & .519 & .212 & .206 & 2.452 & .017 & Significant \\
\hline Moral Leadership (generous) & .610 & .186 & .260 & 3.272 & .002 & Significant \\
\hline \multicolumn{2}{|l|}{$\mathrm{R}$} & \multicolumn{5}{|l|}{0.896} \\
\hline \multirow{2}{*}{\multicolumn{2}{|c|}{$\begin{array}{l}\text { R Square } \\
\text { Adiusted R Square }\end{array}$}} & \multicolumn{5}{|l|}{0.803} \\
\hline & Adjusted R Square & \multicolumn{5}{|l|}{0.782} \\
\hline
\end{tabular}


From the overall results, it can be concluded that the paternalistic leadership aspect has a significant influence on work innovation simultaneously and partially. And from this, it can be seen that the eight independent variables that have the most dominant influence on work innovation are authoritarian leadership because they have the largest beta and t-count coefficients.

\section{CONCLUSION}

Based on the findings of the aforementioned research and literature review, it can be stated that all features of paternalistic leadership are favorably seen by all respondents and have a favorable impact on the formation of Innovation Management for State-owned enterprises Insurance personnel in Indonesia. Authoritarian Leadership is still viewed positively by respondents in contributing to the formation of Innovation management in the Insurance BUMN sector in Indonesia, as evidenced by all characteristics of Paternalistic Leadership.

\section{REFERENCES}

[1] K. R. Novianti, "Cultural dimension issues in Indonesia human resource management practices: a structured literature review," Manag. Econ. J., p. 294, Dec. 2018, doi: 10.18860/mec-j.v0i0.5073.

[2] N. Hamilton-Hart, "Anti-corruption Strategies in Indonesia,” Bull. Indones. Econ. Stud., vol. 37, no. 1, pp. 65-82, 2001.

[3] D. W. Irawanto, Kepemimpinan Esensi dan Realitas. Malang: Bayumedia Publishing, 2008.

[4] K. R. Novianti, "Does Organizational Commitment Matter? Linking Transformational Leadership With Organizational Citizenship Behavior (Ocb)," J. Apl. Manaj., vol. 19, no. 2, pp. 335-345, 2021, doi: 10.21776/ub.jam.2021.019.02.09.

[5] B. S. Cheng, L. F. Chou, T. Y. Wu, M. P. Huang, and J. L. Farh, "Paternalistic leadership and subordinate responses: Establishing a leadership model in Chinese organizations," Asian J. Soc. Psychol., vol. 7, no. 1, pp. 89-117, 2004, doi: 10.1111/j.1467-839X.2004.00137.x.

[6] D. W. Irawanto, P. L. Ramsey, and J. C. Ryan, "Tailoring leadership theory to indonesian culture," Glob. Bus. Rev., vol. 12, no. 3, pp. 355-366, 2011, doi: 10.1177/097215091101200301.

[7] D. W. Irawanto and P. L. Ramsey, "Paternalistic leadership and employee responses in Javanese culture," Gadjah Mada Int. J. Bus., vol. 13, no. 2, pp. 185-203, 2011, doi: 10.22146/gamaijb.5490.

[8] D. W. Irawanto, P. L. Ramsey, and J. C. Ryan, "Tailoring leadership theory to indonesian culture," Glob. Bus. Rev., 2011, doi: 10.1177/097215091101200301.

[9] P. B. Smith, J. Misumi, M. Tayeb, M. Peterson, and M. Bond, "On the generality of leadership style measures across cultures," J. Occup. Psychol., vol. 62, no. 2, pp. 97-109, 1989, doi: 10.1111/j.2044-8325.1989.tb00481.x.

[10] G. Hofstede, Culture's Consequences: Comparing Values, Behaviors, Institutions, and Organizations Across Nations. Thousand Oaks, CA.: Sage Publications, 2001.

[11] R. J. House, P. . Hanges, P. . M. Dorfman, and V. Gupta, Culture, Leadership, and Organizations: The GLOBE studies of 62 societies. California: Sage Publication, 2004.

[12] R. J. House et al., "Cultural influences on leadership and organizations: Project GLOBE. In M. J. Gesner, \& V. Arnold (Eds.), Advances in Global Leadership," Stamford, CN, 1999.

[13] R. F. Littrell, I. Alon, and K. W. Chan, "Regional differences in managerial leader behaviour preferences in China," Cross Cult. Manag., vol. 19, no. 3, pp. 315-335, 2012, doi: $10.1108 / 13527601211247071$.

[14] P. G. Martinez, "Paternalism as a Positive Form of Leadership in the Latin American Context: Leader Benevolence, Decision-Making Control and Human Resources Management Practices," in Managing Human Resources in Latin America: An agenda for international leaders, Oxford, UK: Routledge Publishers, 2005.

[15] P. W. Dorfman, J. P. Howell, S. Hibino, J. K. Lee, U. Tate, and A. Bautista, "Leadership in Western and Asian countries: Commonalities and differences in effective leadership processes across cultures," Leadersh. Q., vol. 8, no. 3, pp. 233-274, 1997, doi: 10.1016/S1048-9843(97)90003-5.

[16] H. Wang, K. S. Law, R. D. Hackett, D. Wang, and Z. X. Chen, "Leader-member exchange as a mediator of the relationship between transformational leadership and followers' performance and organizational citizenship behavior," Acad. Manag. J., vol. 48, no. 3, pp. 420-432, 2005, doi: 10.5465/amj.2005.17407908. 
[17] K. Leithwood and D. Jantzi, "A Review of Transformational School Leadership Research 1996-2005," Leadersh. Policy Sch., vol. 4, no. 3, pp. 177-199, 2005, doi: $10.1080 / 15700760500244769$.

[18] B. M. Bass, Leadership and Performance Beyond Expectations. New York: The Free Press, 1985.

[19] D. I. Jung, B. M. Bass, and J. J. Sosik, "Bridging Leadership and Culture: A Theoretical Consideration of Transformational Leadership and Collectivistic Cultures," J. Leadersh. Stud., vol. 2, no. 4, pp. 3-18, 1995, doi: $10.1177 / 107179199500200402$.
[20] D. W. Irawanto, "Strategi Pengembangan Kapasitas SDM melalui Knowledge Management (KM)," J. Apl. Manaj., vol. 5, no. 3, pp. 380-385, 2007.

[21] W. Zhao and J. R. B. Ritchie, "An investigation of academic leadership in tourism research: 1985-2004," Tour. Manag., vol. 28, no. 2, pp. 476-490, 2007, 10.1016/j.tourman.2006.03.007.

[22] D. W. Irawanto, P. L. Ramsey, and D. C. Tweed, "Exploring paternalistic leadership and its application to the Indonesian public sector," Int. J. Leadersh. Public Serv., vol. 8, no. 1, pp. 4-20, 2012, doi: 10.1108/17479881211230637. 